\title{
Situated cognition and learning: From conceptual frameworks to classroom investigations
}

\section{Linda Allal}

Situated cognition and learning have emerged as a major focus of conceptualization and research in education since the late 1980s. This article examines the basic concepts which frame this field of investigation, the diversification of theoretical positions which guide current work, and the lines of debate between advocates of cognitive versus situated perspectives on learning. Recent developments in classroom-based research on situated learning are discussed in two subject-matter areas: writing and mathematics. Certain implications for didactics, as developed in the French-speaking research community, are briefly mentioned. In conclusion, several questions are raised concerning unresolved issues in understanding how to design instructional contexts that foster situated learning.

The title of this article reflects the order adopted in our discussion of situated cognition and learning, starting with conceptual frameworks and moving toward consideration of classroom investigations. This order does not imply a research stance in which theory necessarily precedes practice; in fact, as the studies presented here show, analysis of classroom practice is often a source of theoretical insights about thinking and learning.

\section{Emergence of situated cognition and Learning}

Many ideas underlying situated cognition and learning have been present in educational and epistemological debates since the earliest years of scientific research on how people think and how they learn. Dewey argued, for example, in his 1902 paper on "The child and the curriculum,» that learning should not be thought of as an individual process of knowledge acquisition ("as sheer self-activity»), because «all activity takes place in a medium, a situation, and with reference to its conditions» (1990, pp. 208-209). He also emphasized that "collateral learning," i.e., learning about contextual aspects of an activity, may be more important than acquisition of the content of the lesson itself (Dewey, 1938/1963, p. 48). 
The concept of «situated cognition» and its implications for learning were explicitly set forth, in the context of contemporary research, in a 1989 article by Brown, Collins, and Duguid. After observing that the prevailing approach to knowledge acquisition in schools regards activity and context as «pedagogically useful» but "fundamentally distinct and even neutral with respect to what is learned» (p. 32), the authors stated their basic thesis as follows:

The activity in which knowledge is developed and deployed [...] is not separable from or ancillary to learning and cognition. Nor is it neutral. Rather it is an integral part of what is learned. Situations might be said to co-produce knowledge through activity. Learning and cognition, it is now possible to argue, are fundamentally situated. (p. 32)

Although several strands of this position were present in Resnick's 1987 discussion of «shared cognition" and "contextualized reasoning» in out-of-school learning, Brown et al. (1989) propose a more encompassing framework for studying cognition in and out of school. In their view, learning is a process of "enculturation" in which the opportunity to observe and to practice in situ allows the development of contextualized competencies incorporating the tools and forms of social interaction that are valued in a given cultural community. As a model of instruction, they advocate the idea of "cognitive apprenticeship" embedded a classroom culture of «authentic practices» (in mathematics problem solving, in written communication, in scientific inquiry). Practices are considered as «authentic» if they are similar, in their dynamics and their use of artifacts, to those of craft apprenticeship and to those of professional communities of practitioners (mathematicians, writers, scientists). Cognitive apprenticeship entails processes of social mediation by the teacher, in the form of modeling, coaching, or scaffolding that sustain guided practice on the part of the learner; it also includes interactive articulation of student strategies and shared reflection, as well as individual and collaborative exploration of contextual constraints and resources in new situations (Collins, Brown, \& Newman, 1989).

Brown et al. (1989), like many other researchers, refer to three major sources of ideas which have influenced the conceptualization of situated cognition and learning. First and foremost is the work conducted in an anthropological perspective by Lave and her associates on cognition in everyday settings (Lave, 1988; Rogoff and Lave, 1984) and on processes of participation in a community of practice (Lave \& Wenger, 1991; Wenger, 1998). The second source is the sociocultural (or sociohistorical ${ }^{1}$ ) perspective of Vygotsky and the Russian school of activity theory, and in particular the interpretations of this work by theorists such as Wertsch (1985) and Newman, Griffith, and Cole (1989). A major contribution of these interpretations lies in their emphasis on the bi-directional nature of appropriation during interaction between learner and teacher: As the learner appropriates new skills under the teacher's guidance, the teacher also appropriates aspects of the child's actions into the on-going system of instruction. Vygotsky's zone of proximal development is thus seen as a zone of joint construction of 
shared activity and negotiated meaning. The third source of influence on situated cognition theory comes from studies in linguistics and semiotics of context-dependant meaning (indexicality) which Brown et al. (1989) extend to conceptual knowledge: «A concept, like the meaning of a word, is always under construction» in different contexts of use (p. 33).

Over the past 12 years, work on situated cognition and learning has developed in several different directions (cf., Cobb \& Bowers, 1999; Greeno \& the Middle School Mathematics through Applications Project Group, 1998; Kirshner \& Whitson, 1997; Salomon \& Perkins, 1998, among others). A first category of investigations has focussed on the ways in which social mediation can enhance individual processes and products of learning. These studies concern the role of scaffolding in situations of tutoring (e.g., Lepper, Drake, \& O’DonnellJohnson, 1997), as well as various structures of peer interaction such as cooperative learning (e.g., Slavin, 1994) and scripted collaboration (O’Donnell, 1999). Although these approaches consider social mediation as a central feature of teaching and learning, the achievement of the individual learner, whether on a cognitive or social plane, remains the primary criterion for judging the effectiveness of the instructional situation. Studies of mediation by cultural artifacts (tools, signs, symbol systems and other devices) have enlarged the scope of research on social mediation by taking into consideration not only the effects of the artifacts on individual cognition but also the effects with the artifacts in use for both individual and collective (or distributed) cognition (Salomon, Perkins, \& Globerson, 1991). ${ }^{2}$

The findings from these studies of mediated learning need to be incorporated into a theory of situated cognition but, for the most part, they do not directly address the central issue of such a theory, that is, elucidation of the processes by which contextualized activity becomes part of the content of what is learned. Research inspired more directly from Lave's work and from the sociocultural paradigm has led to new directions of classroom research, particularly in mathematics education, emphasizing the notion of participation in a community of practice as both the process and the goal of learning.

The «situative» approach developed by Greeno et al. (1998) incorporates concepts from situation theory (Barwise \& Perry, 1983) as a basis for the idea that the regular patterns of an individual's participation in a situation "can be conceptualized as that person's attunements to constraints [...] and to affordances» (p. 9). Constraints include regularities of social practices that allow anticipation of outcomes and of modes of interaction, while affordances are the qualities of the system (resources in the environment in conjunction with characteristics of the actors) that support productive interactions. Greeno et al. further suggest that situative theory can subsume and explain both behaviorist and cognitive analyses of learning. Research conducted by Cobb and associates (Cobb, \& Bowers, 1999; Cobb, Gravemeijer, Yackel, McClain, \& Whitenack, 1997; Cobb \& Yackel, 1996) has developed a framework for describing students' reasoning and 
acts of participation in the practices of the microculture of the mathematics classroom. More generally, their interpretative framework attempts to explain learning as a "process of active individual construction, as well as a process of enculturation» (Cobb et al., 1997, p. 221).

For Kirshner and Whitson (1998), most approaches to situated cognition and learning are limited by their tendency to treat «situation" as an entity located in time and space; what is needed, they believe, are "ways to theorize about cognition and community that transcend such physiotemporal domination» (p. 25). They advocate a "reconceptualization" of situated cognition theory based on a broader range of supporting disciplines, a reconceptualization that «probes the physiological, psychoanalytical and semiotic constitution of persons» (p. 9). Of particular interest, in this regard, is the sociological perspective of Walkerdine (1990) which integrates theoretical contributions from contemporary European thinkers, notably Foucault (1977) and Lacan (1977), to forge a framework for describing how "the child» or "the mathematically talented student» are produced as signs by the discursive practices of schools. Whitson (1997), in his own contribution, turns to the semiotic theory of the American philosopher Peirce (1931-1935). From this source, he elaborates an analysis of triadic sign relations as a means of tracing the evolution of students' interpretations of discourse and their participation, or failure to participate, in the linkages among multiple discourse communities. Although these new conceptions offer promising perspectives for understanding the social and semiotic foundations of situated cognition, their implications for instruction are as yet largely undefined. Moreover, it is not clear whether instruction as a deliberate enterprise of promoting learning is a major concern for these thinkers.

\section{Cognitive versus situated perspectives}

Although situated theory is often seen, and often positions itself, as a "newcomer» trying to overthrow the hegemony of cognitive theory, this state of affairs is not in fact entirely new. In his discussion of trends in the contemporary psychology of his time, Dewey (1902/1990) noted that «earlier psychology regarded mind as a purely individual affair in direct naked contact with an external world [...]. At present the tendency is to conceive of the individual mind as a function of social life [...] requiring continual stimulus from social agencies, and finding its nutrition in social supplies» (pp. 98-99).

Dewey's views not withstanding, cognitive theories of the individual mind have become, over the past 50 years, a major paradigm in psychology and have had a substantial impact on conceptions of instruction. The debate between supporters of a cognitive perspective on learning and the advocates of a situated (or situative) perspective has therefore received a great deal of attention in recent publications on educational research. An initial article by Anderson, Reder, and 
Simon (1996) disputed the major theses that they attribute to theories of situated learning. Greeno (1997) answered by arguing that these criticisms are misreadings of situative theory, due to differences in language and conceptual framing. A reply by Anderson, Reder, and Simon (1997), and the subsequent articles by Sfard (1998), Kirshner and Whitson (1998) and Cobb and Bowers (1999), have pursued the discussion of differences between cognitive and situated positions. Certain points of agreement between the two positions were recently defined in an article by Anderson, Greeno, Reder, and Simon (2000). Our reflection on the debate will deal with two major issues: the units of analysis favored by each perspective and the problem of transfer or generalization of learning across situations.

\section{Units of analysis}

In the cognitive perspective, the basic unit of analysis is the individual and the knowledge the learner acquires while carrying out a task, alone or with others, in a given environment. A clear demarcation is introduced between the individual as learner and the social as one dimension among others of the learning environment. The importance of the social is not denied, but as Anderson et al. (1997) state, the cognitive approach «does try to understand the social through its residence in the mind of the individual» (p. 21). In the situated perspective, starting with Lave (1988), individual and social units of analysis are defined concomitantly in a dialectical relationship. Analysis is focused on the participation of individuals in the social practices of a community and it is postulated that individual participation and collective practices are mutually co-determined. Learning is thus identified with changes in how an individual participates in an evolving community of practice (Greeno, 1997). Cobb et al. (1997) accept the principle of co-determination within a unified system but consider that individual and social processes are separable for purposes of analysis. This view is illustrated by Cobb and Bowers (1999) in a comparison of two studies of arithmetical reasoning, one adopting collective activity as the unit of analysis and the other individual students' acts of reasoning.

Several authors (Cobb et al., 1997; Kirshner \& Whitson, 1998) attribute to Vygotskian sociocultural theory a deterministic social bias focused on the appropriation of culture across generational boundaries. These commentaries recognize the central role that Vygotsky gave to social and semiotic mediation but tend to overlook his interest in the individual developing person, as illustrated in the research he conducted on concept formation (Van der Veer \& Valsiner, 1994; Vygotsky, 1931/1994). It is useful, in this respect, to recall that sociocultural theory was formulated as a theory of human psychology.

It is also important to recognize that the psychological and the social are not just two poles of a dialectical relation but that each permeates the other. Research on situated cognition has shown that individual activity always includes a social component, present through mental evocation of social practices or through 
cultural artifacts used while carrying out the task at hand (Greeno, 1997). Equal recognition needs to be given to the role that individual activity plays in the shaping of social interaction and practice (Damon, 1991; Salomon \& Perkins, 1998).

Transfer

In the cognitive perspective on learning, knowledge is an entity that is acquired in a one task environment and then used or transferred to other situations and contexts (Anderson et al., 1996). It is believed, moreover, that the primary goal of instruction is to foster the acquisition of knowledge represented mentally in a sufficiently general, symbolic form so as to be easily transferable to new situations. The advocates of the situated/situative perspective consider knowledge to be much more context bound precisely because how a skill or concept is learned is a part of what is learned (Brown et al., 1989). The notion of learning as participation in a community of practice even raises the question as to the existence of an entity called knowledge outside the context of its elaboration.

Attempts to look for common ground between the two perspectives show that similar problems are being addressed, even though the explanatory concepts remain grounded in radically different theories. Both perspectives agree that it is necessary to explain how people use existing competencies when engaging in activities that are never identical to previous experiences. For cognitive psychologists, "transfer between tasks is a function of the degree to which tasks share cognitive elements» (Anderson et al., 1996, p. 7). In the situative perspective proposed by Greeno (1997), transfer is explained by the «consistency or inconsistency of patterns of participatory processes across situations» (p. 12). Transfer occurs when constraints and affordances (defined as person-environment relationships) are invariant over transformations of context (Greeno, Smith \& Moore, 1993).

Research in the cognitive perspective has shown that knowledge needs to be taught in several task environments to facilitate broad transfer (Anderson at al. 1996). In a similar vein, some studies of situated learning have emphasized the process of "recontextualization» (Mercer, 1992) by which a developing competency adapts and extends its range of expression to respond to new situational demands. The role attributed to instruction by the two perspectives also shows some analogies. For cognitive psychologists, instruction can increase attention to relevant cues and thereby increase the probability of transfer; in a situated perspective, Rogoff (1995) has defined "guided participation» as a form of instruction which enhances generalization or transfer. In more global terms, Engelström and Cole (1997), referring to Lemke (1997), underline the interpenetrations among communities of practice and the multiplicity of individual participation in different communities as an explanation of the "polycontextuality of learning and cognition» (p. 307), which, they argue, could account for transfer on another basis than the cognitive notion of abstraction. 


\section{Situated Learning in the classroom}

The conceptualization of situated cognition and learning has advanced at a more rapid pace than the systematic investigation of these phenomena in the classroom. Discourse has outstripped the gathering of empirical evidence and the studies which have been conducted are often limited in their scope and findings. It is worthwhile, however, to point out several salient aspects of classroom research in two subject matter areas: writing and mathematics.

\section{Learning to write in context}

Resnick (1990) has defined several features of observed classroom environments which favor «literacy apprenticeship» comparable to authentic literacy practices outside of school:

Children work to produce a product that will be used by others [...]: They work collaboratively, but under conditions in which individuals are held responsible for their work; they use tools and apparatus appropriate to the problem; they read and critique each other's writing; they are called upon to elaborate and defend their own work until it reaches a community standard. (p. 183)

These basic concerns of situated learning are present, more or less explicitly, in many contemporary approaches to writing instruction (e.g., Cameron, Hunt, \& Linton 1996; Englert, Raphael \& Anderson, 1992; Graves, 1983; Schneuwly, 1995).

In contextualized writing activities, rhetorical considerations linking writer, audience and topic can be treated in several different ways. One obvious way is to emphasize production of texts addressed to well-defined audiences outside the classroom, and in particular to audiences which are likely to respond and thereby engage students in an authentic process of communication (e.g., Schneuwly \& Bain, 1993; Florio-Ruane \& Lensmire, 1989). Other approaches are focused more on voice: Students are encouraged to choose topics and develop a style that reflects their cultural identity within a community, as a member of an ethnic group, or as a woman, for example. Still another approach gives priority to the classroom itself as a "writing community.» In this case, the primary audience is composed of the class members who read and discuss one another's texts and who participate in collaborative writing projects. The teacher is also an active member of the community, coaching and critiquing student work, but also modeling writing in front of the students (e.g., Heath \& Branscombe, 1989). In our own research, contextualization of writing addressed to audiences both inside and outside the classroom is seen as a framework for fostering interactive peer regulation and metacognitive self-regulation during different phases of text production (Allal, 2000; Allal et al., 2001). 


\section{Participation in mathematics problem solving}

Mathematics education is a major arena for the development of classroom-based research conducted in a situated perspective. Two leading advocates of the situated, or situative, viewpoint - Cobb and Greeno - have formulated systematic programs of research on mathematics instruction and on uses of mathematics in other disciplines. Other researchers, notably Lampert (1990) and Schoenfeld (1994), have made significant contributions to understanding the contexts and practices of mathematics education.

Greeno et al. (1998) describe their approach as «interactive research and design» in which inquiry originates in the analysis of activities and practices in the classroom, rather than in laboratory studies which are subsequently transposed to schools (p. 21). Collaboration between researchers and practitioners aims at creating a research community that fosters situative analysis of both innovative and ordinary classroom practices. In current publications, the theoretical grounding and general principles of this approach are developed in more detail than the methods of analysis and the findings. To illustrate situative analysis, Greeno et al. (1998) present an example of an episode (teacher-student conversation) drawn from a project of students working on the design of living and working space for scientists in Antarctica. Their presentation concludes, in a very tentative way, that the conversation «includes evidence that learning may have occurred, as the teacher may have become attuned to constraints and affordances of reasoning that she was not attuned to at the beginning» (p. 13). The authors are aware, however, that this type of anecdotal evidence is not sufficient to demonstrate the impact of processes of attunement and participation on student learning. One point of agreement between Greeno and psychologists working in the cognitive perspective is that educational interventions should be analyzed and evaluated with "rigorous research methods» (Anderson et al., 2000, p. 13).

Cobb and his associates (Cobb \& Bauersfeld, 1995; Cobb \& Bowers, 1999; Cobb et al., 1997; Cobb \& Yackel, 1996) have developed an integrated interpretative framework for analyzing the microculture of the mathematics classroom community. Their analysis includes both psychological processes (students' mathematical interpretations, beliefs, values) and social processes (classroom mathematical practices, sociomathematical norms, classroom social norms). Similarly to Greeno et al., they advocate a form of «developmental research» entailing close collaboration between researchers and practitioners as a means of validating and extending the situated perspective (Cobb \& Bowers, 1999).

Certain publications of this group focus on the elaboration of specific components of the interpretative framework, for example the interactive constitution of sociomathematical norms concerning acceptable mathematical explanations or justifications in a second-grade classroom (Yackel \& Cobb, 1996). Through a more in-depth presentation of a case study of mathematics instruction in a firstgrade classroom, observed over a three-month period, Cobb et al. (1997) provide a well-documented qualitative account of the functioning and the interplay 
among the various psychological and social components of their interpretive framework. The analysis gives examples of active individual construction on the part of selected students, while also showing that participation is a process of enculturation in the practices of the classroom community. In addition, this study integrates Walkerdine's (1988) notion of discursive elaboration of a chain of significance to describe the process of mathematization through which, over the course of successive instructional activities, partial meanings attached to concrete objects manipulated by the students become integrated into more abstract semiotic formulations, such as number sentences.

\section{Processes and situations of co-construction}

One aspect of the work by Cobb and associates links up in an interesting way, in our opinion, with earlier classroom observations by Newman et al. (1989). The question can be raised as to how teacher-student interactions actually produce opportunities for construction of knowledge. Newman et al. point to the «indeterminacy» of these interactions as a key factor in reciprocal appropriation and learning:

Just as children do not have to know the full cultural analysis of a tool to begin using it, the teacher does not have to have a complete analysis of the children's understanding of the situation to start using their actions in the larger system. ( $\mathrm{p}$. 63).... [In an instructional dialogue], the participants can act as if their understandings are the same. At first, this systemic vagueness about what an object "really is" may appear to make cognitive analysis impossible. However, it now appears that this looseness is just what is needed to allow change to happen when people with differing analyses interact. (p. 62)

The observations by Cobb et al. (1997) also lend support to the idea that learning takes place through the emergence of a "taken-as-shared mathematical reality» co-constructed by teacher-student interaction (p. 220). This reality incorporates aspects of the classroom participation structure but also the mathematical content acted on during the instructional sequence.

In the situated perspective, authentic activities are often seen as activities developed in a community of practice outside school and then integrated, with appropriate adaptations, into the culture of the classroom. Several commentaries have insisted, however, that it is not the surface similarity of classroom activities to real-life activities that is critical, but rather the fact that classroom activities develop authentic strategies and practices that the student can use outside of school (Brown et al., 1993). Authenticity thus has more to do with how students and teachers interact, how students collaborate, how they use cultural artifacts and tools, than with the format of the tasks undertaken. A task designed to simulate an out-of-school problem-solving situation might be carried out within a transmissive, teacher-dominated lesson, whereas a classic school task (e.g., filling out a worksheet) might become the object of participatory interaction mirroring the qualities of exchanges between practitioners outside school. 
Research conducted in a situated perspective has at least two implications with respect to the conception of subject-matter didactics as elaborated in the French-language research community. A first implication concerns the concept of didactical transposition, i.e., the transformation of scientific knowledge into instructional content, as described by Chevallard (1985). Although it is clear that disciplinary objects of knowledge are brought into the classroom by teachers and by curricular artifacts, situated learning implies a process of knowledge construction that is not simply the last stage in a linear model of transformation. If how students learn is part of what they learn, then the concept of transposition needs to take into account instructional practices and broader sociocultural practices within which bodies of knowledge are elaborated. A second implication concerns the "didactical contract» linking students, teacher and objects of knowledge (Brousseau, 1980). The Newman et al. notion of indeterminacy allows us to look at the didactical contract less as a set of well-defined habits and expectations (revealed primarily in cases of breakdowns) than as a loosely-coupled framework for negotiating meaning and co-producing knowledge. This coincides, as least in part, with the observation by Schubauer-Leoni (1986) that each actor, student and adult, «defines the situation as it unfolds which means that their 'agreement' does not necessarily concern the same objects at the same point in time» (p. 152, our translation).

\section{Unresolved issues}

In conclusion to this article, we examine three unresolved issues that need to be dealt in order to design instruction attuned to situated cognition and learning.

1. It is a postulate of the situated perspective that all human cognition and learning are embedded in situations that permeate psychological processes. As Greeno et al. (1998) state, the issue is not "whether learning is situated or not, but how it is situated» (p. 14). Bereiter (1987), in a critical discussion of this perspective, raises a different question: Are there aspects of situated cognition and learning that, however much a part of human culture, need to be "overcome»? He suggests that the specificity of schooling, as a community of practice, is that the work to be accomplished is "work with knowledge» (p. 298), moreover, the primary characteristic of school work with knowledge is that it needs to go «beyond what the situation calls for» (p. 288). Bereiter also points to the role of individual intentionality in determining how, in a same learning situation, constraints and affordances may differ from one learner to another. We can restate this concern as follows: The notion of agency has yet to find a clearly defined place in theories of situated cognition and learning. 
2. At a conceptual level, the notion of learning as participation offers a promising, new way of looking at instructional processes. It needs to be recognized, however, that the implications of this notion have not yet been thoroughly explored in classroom-based research. Several questions under investigation in an on-going study by Mottier Lopez (2001) include the following preoccupations: Is participation in the classroom microculture sufficient for appropriation of social practices and for progression of conceptual understanding? Do all students participate in the co-constitution of classroom culture? By participating do students learn to participate? More generally speaking, it is difficult to study the activity of participation without looking for individual cognitive and/or social competencies produced through this activity. Participation is a particularly slippery notion when confronted with social demands for accountability in teaching. Is it sufficient, for example, for a teacher to tell parents that a student has participated consistently in classroom activities without any further statement about competence manifested with respect to the objects of knowledge dealt with in the activities?

3. In Schoenfeld's 1999 presidential address to the American Educational Research Association, he stated that one of the challenges for the 21 st century is the creation of a unified theory of cognitive and social processes that explains thinking, acting and being. Although many would agree that learning implies a «reciprocal spiraling relationship» between these processes (Salomon \& Perkins, 1998), the mechanisms of the spiral have yet to be adequately uncovered. The situated perspective offers some fruitful starting points for this endeavor. We also think it allows, as described elsewhere (Allal et al., 2001), a renewal of the concept of a spiral curriculum (Bruner, 1960) in which complex, authentic learning activities are articulated with more specific skilloriented tasks in instructional sequences that help learners move into new realms of practice and understanding.

\section{Acknowledgements}

I would like to thank Laurence Rieben and Lucie Mottier Lopez for their comments on an initial version of this article.

\section{Notes}

1 Although the term «sociohistorical» is often preferred when referring to Vygotsky's work, the term «sociocultural» is used in this article because it appears more frequently in the English language literature on situated cognition and learning.

2 A simplified example of this distinction would be the effect of efficient use of a spell-checker on an individual's capacity to produce correctly written texts (effects with) versus the effects of regular use of the spell-checker on an individual's capacity to write correctly even when the spell-checker is not available (effects of). 


\section{References}

Allal, L. (2000). Metacognitive regulation of writing in the classroom. In A. Camps \& M. Milian (Eds.), Metalinguistic activity in learning to write (pp. 145-166). Amsterdam: Amsterdam University Press.

Allal, L., Bétrix Koehler, D., Rieben, L., Rouiller Barbey, Y., Saada-Robert, M. \& Wegmuller, E. (2001). Apprendre l'orthographe en produisant des textes. Fribourg: Editions Universitaires.

Anderson, J. R., Greeno, J. G., Reder, L. A. \& Simon, H. A. (2000). Perspectives on learning, thinking and activity. Educational Researcher, 29 (4), 11-13.

Anderson, J. R., Reder, L. A. \& Simon, H. A. (1996). Situated learning and education. Educational Researcher, 25 (4), 5-11.

Anderson, J. R., Reder, L. A. \& Simon, H. A. (1997). Situative versus cognitive perspectives: Form versus substance. Educational Researcher, 26 (1), 18-21.

Barwise, J. \& Perry, J. (1983). Situations and attitudes. Cambridge, MA: MIT Press.

Bereiter, C. (1987). Situated cognition and how to overcome it. In D. Kirshner \& J. A. Whitson (Eds.), Situated cognition: Social, semiotic and psychological perspectives (pp. 281-300). Mahwah, NJ: Erlbaum.

Brousseau, G. (1980). L'échec et le contrat. Recherches, 41, 177-182.

Brown, A., Ash, D., Rutherford, M., Nakagawa, K., Gordon, A. \& Campione, J. C. (1993). Distributed expertise in the classroom. In G. Salomon (Ed.), Distributed cognitions: Psychological and educational considerations (pp. 188-228). Cambridge, UK: Cambridge University Press.

Brown, J. S., Collins, A. \& Duguid, P. (1989). Situated cognition and the culture of learning. Educational Researcher, 18 (1), 32-42.

Bruner, J. S. (1960). The process of education. New York: Vintage.

Cameron, C. A., Hunt, A. K. \& Linton, M. J. (1996). Written expression as recontextualization: Children write in social time. Educational Psychology Review, 8, 125-150.

Chevallard, Y. (1985). La transposition didactique: Du savoir savant au savoir enseigné. Grenoble: La Pensée Sauvage.

Cobb, P. \& Bauersfeld, H. (Ed.). (1995). Emergence of mathematical meaning: Interaction in classroom cultures. Hillsdale, NJ: Erlbaum.

Cobb, P. \& Bowers, J. (1999). Cognitive and situated learning: Perspectives in theory and practice. Educational Researcher, 28 (2), 4-15.

Cobb, P., Gravemeijer, K., Yackel, E., McClain, K. \& Whitenack, J. (1997). Mathematizing and symbolizing: The emergence of chains of significance in one first-grade classroom. In D. Kirshner \& J. A. Whitson (Ed.), Situated cognition: Social, semiotic and psychological perspectives (pp. 151-233). Mahwah, NJ: Erlbaum.

Cobb, P. \& Yackel, E. (1996). Constructivist, emergent, and sociocultural perspectives in the context of developmental research. Educational psychologist, 31, 175-190.

Collins, A., Brown, J. S. \& Newman, S. E. (1989). Cognitive apprenticeship: Teaching the craft of reading, writing, and mathematics. In L. S. Resnick (Ed.), Knowing, learning, and instruction (pp. 449-453). Hillsdale, NJ: Erlbaum.

Damon, W. (1991). Problems of direction in socially shared cognition. In L. B. Resnick, J. M. Levine \& S. D. Teasdale (Eds.), Perspectives on socially shared cognition (pp. 384-395). Washington, DC: American Psychological Association.

Dewey, J. (1902/1990). The child and the curriculum. Chicago: University of Chicago Press.

Dewey, J. (1938/1963). Experience and education. New York: Collier.

Engelström, Y. \& Cole, M. (1997). Situated cognition in search of an agenda. In D. Kirshner \& J. A. Whitson (Eds.), Situated cognition: Social, semiotic and psychological perspectives (pp. 301-309). Mahwah, NJ: Erlbaum.

Englert, C. S., Raphael, T. E. \& Anderson, L.M. (1992). Socially mediated instruction: Improving students' knowledge and talk about writing. The Elementary School Journal, 92, 411-444. 
Florio-Ruane, S. \& Lensmire, T. (1989). The role of instruction in learning to write. In J. Brophy (Ed.), Advances in research on teaching. Vol. 1 (pp. 73-104). Greenwich, CT: JAI Press.

Foucault, M. (1977). Discipline and punishment: The birth of the prison (A. Sheridan, Trans.). New York: Pantheon.

Graves, D. H. (1983). Writing: Teachers and children at work. Portsmouth, NH: Heinemann.

Greeno, J. G. (1997). On claims that answer the wrong questions. Educational Researcher, 26 (1), 5-17.

Greeno, J. G. \& the Middle School Mathematics through Applications Project Group. (1998). The situativity of knowing, learning, and research. American Psychologists, 53, 5-26.

Greeno J. G., Smith, D. R. \& Moore, J. L. (1993). Transfer of situated learning. In D. K. Detterman \& R. J. Sternberg (Ed.), Transfer on trial: Intelligence, cognition, and instruction (pp. 99-167). Norwood, NJ: Ablex.

Heath, S. B. \& Branscombe, A. (1989). «Intelligent» writing in an audience community: Teacher, students and researcher. In S. W. Freedman (Ed.), Research in the teaching of English, 21, 331-361.

Kirshner, D. \& Whitson, J. A. (Ed.). Situated cognition: Social, semiotic and psychological perspectives. Mahwah, NJ: Erlbaum.

Kirshner, D. \& Whitson, J. A. (1998). Obstacles to understanding cognition as situated. Educational Researcher, 27 (8), 22-28.

Lacan, J. (1977). Ecrits: A selection (A. Sheridan, Trans.). New York: Norton.

Lampert, M. (1990). When the problem is not the question and the solution is not the answer: Mathematical knowing and teaching. American Educational Research Journal, 27, 29-63.

Lave, J. (1988). Cognition in practice: Mind, mathematics and culture in everyday life. Cambridge, UK: Cambridge University Press.

Lave, J. \& Wenger, E. (1991). Situated learning: Legitimate peripheral participation. Cambridge, UK: Cambridge University Press.

Lemke, J. L. (1997). Cognition, context, and learning: A social, semiotic perspective. In D. Kirshner \& J. A. Whitson (Ed.), Situated cognition: Social, semiotic and psychological perspectives (pp. 37-55). Mahwah, NJ: Erlbaum.

Lepper, M. R., Drake, M. F. \& O’Donnell-Johnson, T. (1997). Scaffolding techniques of expert human tutors. In M. Pressley \& K. Hogan (Ed.), Advances in teaching and learning (pp. 108-144). New York: Brookline.

Mercer, N. (1992). Culture, context and the construction of knowledge in the classroom. In P. Light \& G. Butterworth (Ed.), Context and congition: Ways of learning and knowing (pp. 28-46). London: Harvester Weatsheaf.

Mottier Lopez, L. (2001). L'interaction collective dans la classe de mathématiques: Observation de la participation aux pratiques sociales de la communauté classe en 3ème année primaire. Canevas de thèse en sciences de l'éducation, Université de Genève.

Newman, D., Griffith, P. \& Cole, M. (1989). The construction zone: Working for cognitive change in school. Cambridge, UK: Cambridge University Press.

O’Donnell, A. M. (1999). Structuring dyadic interaction through scripted cooperation. In A. M. O’Donnell \& A. King (Ed.), Cognitive perspectives on peer learning (pp. 179-196). Mahwah, NJ: Erlbaum.

Peirce, C. S. (1931-1935). Collected papers of Charles Sanders Peirce (Vols. 1-6, C. Hartshorn \& P. Weiss, Ed.). Cambridge, MA: Harvard University Press.

Resnick, L. B. (1987). Learning in school and out. Educational Researcher, 16 (9), 13-20.

Resnick, L. B. (1990). Literacy in school and out. Daedalus, 119, 169-185.

Rogoff, B. (1995). Observing sociocultural activity on three planes: Participatory appropriation, guided participation, and apprenticeship. In J. V. Wertsch, P. del Rio \& A. Alvarez (Ed.), Sociocultural studies of the mind (pp. 139-164). Cambridge, UK: Cambridge University Press. 
Rogoff, B. \& Lave, J. (Ed.). (1984). Everyday cognition: Its development in social context. Cambridge, MA: Harvard University Press.

Salomon, G. \& Perkins, D. N. (1998). Individual and social aspects of learning. In P. D. Pearson \& A. Iran-Nejad (Ed.), Review of Research in Education. Vol. 23 (pp. 1-25). Washington, DC: American Educational Research Association.

Salomon, G., Perkins, D. N. \& Globerson, T. (1991). Partners in cognition: Extending human intelligence with intelligent technologies. Educational Researcher, 20(3), 2-9.

Schneuwly, B.(1995). Apprendre à écrire: Une approche socio-historique. In J.-Y. Boyer (Ed.), La production écrite: Vers un modèle d'enseignement de l'écriture (pp. 70-100). Montréal: Logiques.

Schneuwly, B. \& Bain, D. (1993). Mécanismes de régulation des activités textuelles: Stratégies d'intervention dans les séquences didactiques. In L. Allal, D. Bain \& P. Perrenoud (Ed.), Evaluation formative et didactique du français (pp. 219-239). Neuchâtel: Delachaux et Niestlé.

Schoenfeld, A. H. (Ed.). (1994). Mathematical thinking and problem solving. Hillsdale, NJ: Erlbaum.

Schoenfeld, A. H. (1999). Looking toward the 21st century: Challenges of educational theory and practice. Educational Researcher, 28 (7), 4-14.

Schubauer-Leoni, M.-L. (1986). Le contrat didactique: Un cadre interprétatif pour comprendre les savoirs manifestés par les élèves en mathématique. European Journal of Psychology of Education, 1, 139-153.

Sfard, A. (1998). On two metaphors for learning and the dangers of choosing just one. $E d u-$ cational Researcher, 27 (2), 4-13.

Slavin, R. (1994). Cooperative learning: Theory, research and practice (2nd ed.). Boston: Allyn \& Bacon.

Van der Veer, R. \& Valsiner, J. (1994). Introduction. In R.Van der Veer \& J. Valsiner (Ed.), The Vygotsky reader (pp. 1-9). Oxford: Blackwell.

Vygotsky, L. S. (1931/1994). The development of thinking and concept formation in adolescence. In R. Van der Veer, R. \& J. Valsiner (Ed.), The Vygotsky Reader (pp. 185-265). Oxford: Blackwell.

Walkerdine, V. (1988). The mastery of reason: Cognitive development and the production of rationality. London: Routledge.

Walkerdine, V. (1990). Schoolgirl fictions. London: Verso.

Wenger, E. (1998). Communities of practice: learning, meaning and identity. Cambridge, UK: Cambridge University Press

Wertsch, J. V. (1985). Vygotsky and the social formation of the mind. Cambridge, MA: Harvard University Press.

Whitson, J. A. (1997). Cognition as a semiosic process: From situated mediation to critical reflective transcendence. In D. Kirshner \& J. A. Whitson (Ed.), Situated cognition: Social, semiotic and psychological perspectives (pp. 97-149). Mahwah, NJ: Erlbaum.

Yackel, E. \& Cobb, P. (1996). Sociomathematical norms, argumentation, and autonomy in mathematics. Journal for Research in Mathematics Education, 27, 458-477. 


\section{Situierte Kognition und situiertes Lernen: von konzeptionellen Rahmenbedingungen zu Studien in Klassensituationen}

\section{Zusammenfassung}

Studien über situierte Kognition und situiertes Lernen stellen seit Ende der 1980er-Jahre einen Schwerpunkt für Konzepte und Forschung im Bildungsbereich dar. Der vorliegende Beitrag beschäftigt sich mit grundlegenden Konzepten, die dieses Feld näher definieren, mit der Vielzahl der theoretischen Positionen, an denen sich aktuelle Studien orientieren, und mit dem Diskurs zwischen den Befürwortern der situierten Lernmethode und denjenen, die den kognitiven Ansatz verteidigen. Neue Entwicklungen in der Forschung über situiertes Lernen in der Schulklasse werden für zwei Schulfächer vorgestellt: schriftlicher Ausdruck und Mathematik. Zudem werden einige Implikationen für die französischsprachige Didaktikforschung erwähnt. Zum Schluss werden im Hinblick auf das Schaffen von didaktischen Umfeldern, die situierten Lernprozessen zuträglich sind, mehrere Fragen zu momentan noch ungelösten Problemen gestellt.

\section{Cognition et apprentissage situés: des cadres conceptuels aux études en situation de classe}

\section{Résumé}

Les travaux sur "situated cognition and learning» sont devenus, depuis la fin des années 1980, une centration principale de conceptualisation et de recherche en éducation. Cet article examine les concepts de base qui définissent ce champ, la diversification des positions théoriques qui orientent les travaux actuels et les lignes des débats entre les partisans de l'étude de l'apprentissage selon une perspective cognitive versus les défenseurs d'une perspective située. Les développements récents de recherches sur l'apprentissage situé dans le cadre de la classe sont présentés dans deux disciplines scolaires: l'expression écrite et les mathématiques. Quelques implications pour les travaux francophones en didactique sont mentionnées. En conclusion, plusieurs questions sont soulevées concernant des problèmes non résolus en vue de l'élaboration de contextes didactiques favorables aux processus d'apprentissage situé. 


\section{Cognizione e apprendimento in situazione: quadri concettuali e studi sulle situazioni di classe}

\section{Riassunto}

A partire dagli anni '80 gli studi sul «situated cognition and learning» sono diventati uno degli ambiti principali della ricerca e della concettualizzazione nelle scienze dell'educazione. Il contributo esamina i concetti di base che delimitano questo ambito di studio, le diverse posizioni teoriche e il dibattito che vede contrapporsi i fautori di un approccio cognitivista a coloro che difendono la posizione di un apprendimento centrato sulla «situated cognition». Gli sviluppi recenti delle ricerche sulla "situated cognition» in contesto di classe vengono poi presentati con riferimento alla matematica e all'espressione scritta. Inoltre si fa cenno ad alcune implicazioni per la ricerca francofona in didattica e si conclude sollevando diverse questioni concernenti problemi irrisolti per la creazione di ambienti didattici favorevoli all'apprendimento centrato sulla "situated cognition». 